\title{
Stages of a Mathematical Model Developing of the Educational Trajectory
}

\author{
Krupa Tatiana
}

\begin{abstract}
The model is based on the use of interactive teaching methods. A characteristic feature of the use of interactive technologies is the organization of training that takes into account the inclusion of all the students of a group without exception in the learning process. Joint activity means that each participant makes his or her own individual contribution, whereby in the course of work there is an exchange of knowledge, ideas, and methods of activity. An environment of educational communication is created that is characterized by openness, interaction of participants, equality of their arguments, accumulation of common knowledge, and the possibility of mutual evaluation and control.

The use of neural networks to study and predict educational assets will provide research and development organizations and teams with innovative and effective ways of conducting research in the field of educational theory, modeling of the cognitive processes related to formation of different student competencies, and devising more appropriate methods for estimating student educational outcomes.
\end{abstract}

Keywords: mathematical model, machine learning, GlobalLab, educational trajectory, Jupyter Notebook, GNU Octave s

\section{INTRODUCTION}

Each discipline has different ways of responding to questions and solving problems: for example, research using scientific methods, historical analysis, literature review, and mathematical modeling. Survey methods, knowledge-finding tools, and evidence-based methods are also critical to curriculum development. When students learn to use these research methods, they train their minds differently (which is the initial reason for introducing disciplines) and are more likely to develop disciplinary skills. A form of deep learning. Structural disciplines that can be used in organizing the curriculum to engage students in these basic ideas and research methods also provide means for conveying other ideas, topics, and problems to and from school life [25, 27].

The use of machine learning methods for the formation of personal education pathways due to the whole or part of automation enhances the cost of individual training, which, as many have shown domestic and foreign pedagogical instruction, have a positive impact on the level of educational outcomes [1, 12, 16, 24, 26]

Revised Manuscript Received on February 18, 2020.

* Correspondence Author

Krupa Tatiana*, GlobalLab, LLC, Moscow, Russia. Email: krupa.tatiana@mail.ru

(C) The Authors. Published by Blue Eyes Intelligence Engineering and Sciences Publication (BEIESP). This is an open access article under the CC BY-NC-ND license (http://creativecommons.org/licenses/by-nc-nd/4.0/)

\section{Learning trajectory in mathematics education}

The concept of an educational trajectory has a long history of developmental psychology, beginning to recognize that children are not small, non-adult adults; rather, they often build their understanding of the world through their experiences and interactions with others, and their insights into ideas stemming from insanity are much more sophisticated [14, 15]. This recognition has led many scientists to satisfy curiosity to understand how children, in particular, and, to some extent, embarrassed students, perceived events and ideas. Piaget and his colleagues have prepared a global research program to document children's ideas and showcase children's amazing knowledge in building their understanding, which may make a difference from in the more complex point of view of an adult [17-19]. Understanding this and knowing how to put it in teaching is important for teachers, especially for those who are serious about the idea that "you have to start from where the student is". Working from a constructivist point of view, Simon (1995) answers a specific question about how a teacher can provide tools to help students move from their prior ideas to more complex thinking about the target concept. At the same time, he proposes a "hypothetical learning trajectory" (HLT), which includes "the purpose of learning, learning actions, as well as thinking and learning, in which students participate" [13, 20-22]. Based on this, significant research efforts have been made in this area to quantify students 'long-term teaching pathways as a model of the evolution of students' thinking as part of their slow approach to targeted ideas.

The use of machine learning methods for the formation of personal educational paths through full or partial automation will significantly reduce the cost of individualization of training, which, as many domestic and foreign pedagogical studies show, has a positive effect on the level of educational results [6, 23].

\section{METHODOLOGY}

Arrays of data from the GlobalLab online platform and the electronic diary Diary.ru were used to form a model of the student's educational trajectory.

For mathematical modeling, Jupyter Notebook, GNU Octave software was used.

The analysis of patent documents and computer program registration certificates shows that to date there have been no inventions describing the use of specific machine learning techniques for modeling applications. properties of educational pathways. Usually, the object of protection is not a specific model, but rather the method of its application to a much larger model utility. 


\section{Stages of a Mathematical Model Developing of the Educational Trajectory}

Methods based on the use of specific data to input models of educational and student trajectories are also protected.

The direction of the mathematical model of education that makes us possible to compose a list of activities and events

1. The student's educational course of activities was added to the preliminary list.

According to the results of the analysis, such activities were divided into 2 groups. The first group consists of events in the direction of simple steps, and the second, also taking into account the user's success/failure. This division is assigned to the second group of events that can be used to estimate the direction of the entire educational advancement.

2. This list is a combination of several measures to analyze and electronic diary Dnevnik.ru of their information added.

Dnevnik.ru data events on the second group, a rating event has been added. As well as courses GlobalLab platform, reflecting the results of the check on completion of tasks or events with type 2. These activities, to increase the accuracy of the sequence, and then 100 points, the higher the class, the successful actions 65. This additional education in the direction of the mathematical model is considered to be an opportunity to reflect changes in the student's academic, and compliance [1, 7-11].

\section{RESULT AND DISCUSSION}

The type of events that characterize the trajectory of the Table 1.

Table 1. List of event types taken into account by the mathematical model of the educational trajectory

\begin{tabular}{|l|l|}
\hline No. & Event type \\
\hline Group 1 \\
\hline 1 & The user approves the project. \\
\hline 2 & The user approves the idea. \\
\hline 3 & User approves blog post. \\
\hline 4 & User approves comment. \\
\hline 5 & The user logged in to the system. \\
\hline 6 & The user has activated. \\
\hline 7 & User has registered. \\
\hline 8 & The user has logged out. \\
\hline 9 & The user creates a project. \\
\hline 10 & The user creates an idea. \\
\hline 11 & The user creates a school or group. \\
\hline 12 & The user creates a blog post. \\
\hline 13 & User comments on the project (in discussion). \\
\hline 14 & The user comments on the idea. \\
\hline 15 & The user comments on the blog post (news or project). \\
\hline 16 & The user sends the project for moderation. \\
\hline 17 & $\begin{array}{l}\text { The user saves the questionnaire in the project (does not } \\
\text { send). }\end{array}$ \\
\hline 18 & User edits his profile. \\
\hline 19 & User edits the project. \\
\hline 20 & User is editing a group or school. \\
\hline 21 & User edits portfolio. \\
\hline 22 & User edits an idea. \\
\hline 23 & The user sends the LAN to the user. \\
\hline 24 & A user sends an invitation to another user. \\
\hline Group 2 \\
\hline 25 & User has been tested for GlobalLab (success/failure) \\
\hline 26 & The user received a rating on the subject (success/failure) \\
\hline
\end{tabular}

\begin{tabular}{|l|l|}
\hline 27 & $\begin{array}{l}\text { The user completed the task as part of the GlobalLab } \\
\text { course (success) }\end{array}$ \\
\hline 28 & The user received an award (success). \\
\hline 29 & The user sends the questionnaire to the project (success). \\
\hline 30 & The user received a certificate (success). \\
\hline 31 & $\begin{array}{l}\text { The user's project was not approved by the moderator } \\
\text { (failure). }\end{array}$ \\
\hline 32 & The user profile was blocked by the moderator (failure). \\
\hline 33 & User profile blocked by moderator (failure). \\
\hline
\end{tabular}

In the four-stage model of interest development, earlier stages of interest are dependent on the social environment. As interests become more deeply connected to values, purpose, meaning, and identity, they become increasingly self-sustaining. Choices to learn might include initiating a new project activity, pursuing opportunities for mentoring, deciding to enroll in a formal class, or using technology to engage in personal learning excursions [27].

Within a specific trajectory, decision-making training is conducted at the level to use the decision-making methodology. To support the solution offers a genuinely rational set of facts and operations aimed at choosing one of these years. At various stages, the student is described independently in their subject. One needs to do the best training while creating a strategy for personalized activity [2, 3, 5].

Studying at this stage requires two stages of student activity.

\section{Stage I. Simultaneous repetition.}

Stage II. Setting goals in the process of jointly organized teaching and learning activities.

At this stage, the student chooses a job that can design his jacket.

Individual problems that have specific diagnostic goals are quickly resolved, and each one requires specific questions about the problems that are being used.

It is crucial to master the preparatory process for all, having to inform the student that he can remain the right decision for himself and that he must also see. As a result, the student can offer such a system of indeed (tricks) decision making and individual learning decisions.

\section{Create a subjective view of time}

The student reads the work, presents a set of mathematical problems, distinguishing their components (academic units). It opens information about perception and its initial processing.

\section{Structural information (analysis) to choose from}

The student offers to be offered to learn about what the teacher uses, using complexity. For example, one can suggest the following level:

knowledge level, change, supply level, interesting composition, newer problem, creative or reproductive.

3. Analysis of proposed tasks for selected arteries

When choosing arteries, the student always chooses highly essential results. 


\section{Reduce many alternatives}

Comparison of selected components of a student's task and knowledge and skills. The student may reject some options because of the apparent mismatch of their knowledge and those needed to solving problem.

\section{Realization of an individual choice of tasks}

6. Applying and correcting choices (internalization as the ability of a particular activity based on the most uncomplicated reflective activity).

Students begin to solve the problem. At the same time, it may be that someone has chosen a task that is too easy for themselves and that someone is too complicated. Everyone has the right to choose a different task. In this case, the student should try to understand why he or she chose a task that does not fit his or her abilities.

\section{Distinguish problems in different types of activities}

When solving a problem, students have some difficulties in their activities, which can be caused by inattention, lack of awareness of the task, lack of theoretical and (or) practical knowledge, and characteristics of the task. Students intuitively highlight new issues and their causes.

\section{Problem statement}

By selecting a task of a certain level, the student receives certain information about the readiness to study a topic in mathematics classes and chooses the path of his / her further study: at the level of reproduction of knowledge that he consciously observes and records in memory or at the level of comparing existing knowledge with that which one should receive as a result of mental activities or at the level of new knowledge based on what one have learned

Operating. At this stage, the student solves the problem of how to act. Solutions are in the development of ways to manage situations.

The student learning process at this stage involves two stages of student activity.

Stage III Researching, understanding, reviewing information by students

Stage IV Interpreting information and designing a new course of action.

Organizational. At this stage, the student determines the structure of the learned mode of action. It incorporates it into the knowledge system.

Stage V. Incorporating a new mode of action into the knowledge system.

Stage VI Students evaluate their activities [4].

\section{CONCLUSION}

The final list of events is formed, which are taken into account by the mathematical model of the educational trajectory. The list of events allows us to increase the adequacy of the mathematical model of the educational trajectory by including in it a wide range of educational activities that are not traditionally included in student models.

\section{ACKNOWLEDGMENT}

Applied research described in this paper is carried out with financial support of the state represented by the Ministry of Science and Higher Education of the Russian Federation under the Agreement \#14.576.21.0100 of 26 September 2017 (unique identifier of applied research
RFMEFI57617X0100).

\section{REFERENCES}

1. T. V. Krupa, Theoretical studies of the performed for the Stages of the ASR tasks. Moscow: GlobalLab, LLC, 2018.

2. L. Furukawa, "Trajectory of Learning Experience based on the Performance of Canada's Youth in Mathematics", International Journal of Innovation in Science and Mathematics Education, 26(6), 62-75, 2018.

3. G. Lipatnikova, A. S. Polyanina, "The formation of the target component of educational activities of students using decision-making techniques in the framework of the reflexive approach", Problems and Methods of Teaching Natural Sciences and Mathematics: Materials of the III All-Russian Scientific and Practical Conference (Ekaterinburg, December 2007) (pp. 194-197). Ekaterinburg: Publishing House of the Ural Institute of Economics, Management and Law, 2007.

4. G. Lipatnikova, "The creation on an individual educational thakectory as one of ways to reach students in decision making", Fundamental researches, 5: 108-110, 2009.

5. O. A. Granichina, "Mathematical models of the quality control of the educational process in the university with active optimization", Stokhaisticheskaya optimizatsiya $v$ informatike, 2: 77-108, 2006. Retrieved from https://www.math.spbu.ru/user/gran/sb2/granolga.pdf

6. M. Taguma, F. Gabriel, M. H. Lim, "Future of Education and Skills 2030: Curriculum anaktsis: A synthesis of research on learning trajectories/Progressions in mathematics", OECD. EDU/EDPC(2018)44/ANN3, 2019. Retrieved from https://www.oecd.org/education/2030-project/about/documents/A Synt hesis_of_Research_on_Learning_Trajectories_Progressions_in_Mathe matics.pdf

7. C. Haas, A. Hadjar, "Students' trajectories through higher education: a review of quantitative research", Higher Educarion: 1-20, 2019. DOI: 10.1007/S10734-019-00458-5

8. Anwar, I. Rofiki, "Investigatigating students' leatning trajectory: a case on triangle", Journal of Physics Conference Series, 1088: 012021, 2018 DOI: 10.1088/1742-6596/1088/1/012021

9. "Individual educational trajectory", University of Tyumen, 2019 Retrieved https://www.utmn.ru/en/study-with-us/individual-education/

10.P. Sztajn, J. Confrey, P. H. Wilson, C. Edgington, "Learning Trajectory Based Instructions: Toward a Theory of Teaching", Educational Researcher, 41 (5): 147-156, 2012. Retrieved from https://www.jstor.org/stable/23254092?seq=1

11.D. Siemon, T. Barkatsas, R. Seah, Researching and Using Progressions (Trajectories) in Mathematics Education. Brill, 2019. ISBN 9004396446.

12.D. B. Edwards Jr. The Trajectory of Global Education Policy: Community-Based Management in El Salvador and the Global Reform Agenda. Springer, 2017. ISNB: 1137508752.

13.E. Merzon, E. Galimullina, E. Ljunimova, “A smart trajectory model for teacher training", In Cases on Smart Learning Environments (pp. 164-187), 2019. DOI: 10.4018/978-1-5225-6136-1.ch010

14.D. Johnson, "Comparing the trajectories of educational change and policy transfer in developing countries", Oxford Reciew of Education, 32 (5): 679-696, 2006. 2 Retrieved from https://www.jstor.org/stable/4618689?seq =1

15.M. N. Ryzhkova, "The mathematical model of the process of educayion management", Bestnik Cherepovetskogo gosudarstvennogo universiseta, 6: 41-47, 2015. Retrieved from https://cyberleninka.ru/article/n/matematicheskaya-model-protsessa-upr avleniya-obucheniem

16.P. V. Ovchinnikov, Mathematical Models and Instruments for Designing Adaptive Educational Trajectories for Preparation of Competitive Specialists in Universities: Abstract thesis. Rostov-on-Don, 2014 Retrieved

from http://economy-lib.com/matematicheskie-modeli-i-instrumentariy-proe ktirovaniya-adaptivnyh-obrazovatelnyh-traektoriy-dlya-podgotovki-ko nkurentosp

17.S. A. Vdovina, I. M. Kungurova, "The nature and directions of the individual educational trajectory", Naukovedeniye, 6: 1-8, 2013.

18.M. Brown, "Six trajectories for Digital Technology in Higher Education", Educause review, $2015 . \quad$ Retrieved from https://er.educause.edu/-/media/files/article-downloads/erm1541.pdf

Published By: 


\section{Stages of a Mathematical Model Developing of the Educational Trajectory}

19."Transforming Our World, the 2030 Agenda for Sustainable Development", United Nations General Assembly Resolution A/RES/70/1, 2015. $\quad$ Retrieved from http://www.un.org/ga/search/view_doc.asp?symbol=A/RES/70/1\&Lan $\mathrm{g}=\mathrm{E}$

20.A. C. Antoulas (Ed.), Mathematical System Theory. Berlin: Springer, 1991.

21.J. G. Maree, "Narrative Research in Career Counselling: The Career Construction Interview", In L. Sumaya, F. Angelo, K. Sherianne, Transforming Research Methods in the Social Sciences: Case Studies from South Africa (pp. 186-202). Johannesburg: Wits University Press, 2019. Retrieved from www.jstor.org/stable/10.18772/22019032750.17

22.A. P. Adiredja, "Anti-Deficit Narratives: Engaging the Politics of Research on Mathematical Sense Making", Journal for Research in Mathematics Education, 50 (4): 401-435, 2019. Retrieved from www.jstor.org/stable/10.5951/jresematheduc.50.4.0401

23.M. McCartney, The Indian Economy. Newcastle upon Tyne: Agenda Publishing, 2019. DOI: 10.2307/j.ctvnjbfk1

24.R. L. Geiger, American Higher Education since World War II: A History. Princeton University Press, 2019. Retrieved from www.jstor.org/stable/j.ctv9hvtbz.

25.M. Ndlovu, "Modeling with Sketchpad to enrich students' concept image of the derivative in introductory calculus: developing domain specific understanding", 2008. Retrieved from https://www.researchgate.net/publication/323120414_Modeling_with_ Sketchpad_to_enrich_students'_concept_image_of_the_derivative_in_i ntroductory_calculus_developing_domain_specific_understanding

26.L. Darling-Hammond, L. Flook, C. Cook-Harvey, B. Barron, D. Osher, "Implications for educational practice of the science of learning and development", Applied Developmental Science, 2019. DOI: 10.1080/10888691.2018.1537791

27.S. Hidi, K. A. Renninger, “The four-stage model of interest development", Educational Psychologist, 41 (2): 111-127, 2006. DOI: 10.1207/s15326985ep4102_4 